\title{
Editorial foreword for "environment, development and sustainability" journal
}

\section{Now is the time for researchers to transform the food system}

\author{
Seren Kell ${ }^{1}$
}

Received: 16 December 2021 / Accepted: 16 December 2021 / Published online: 29 January 2022 (c) Springer Nature B.V. 2022

In November 2021, world leaders met for the COP26 summit to make climate decisions that will impact every person on our planet. While some important progress was made towards limiting temperature rises, the negotiations didn't go far enough on the phasing out of fossil fuels or support for countries facing the most devastating impacts of climate breakdown. But one sector was completely absent from the high-level discussions, despite causing $21 \%$ of global emissions (Xu et al., 2021): animal agriculture. Promises were made to cut methane 30 percent by 2030 (Joint US-EU Press Release on the Global Methane Pledge, 2021)_but there was no mention of reducing our reliance on animal farming. This is a truly remarkable oversight, considering $32 \%$ of methane emissions are caused by ruminants (UN Environment Programme, 2021) such as cows and sheep, and their manure. World leaders promised to end deforestation by 2030 (Glasgow Leaders' Declaration on Forests and Land Use-UN Climate Change Conference, 2021), but failed to mention that $60 \%$ of it is caused by the production of animal feed, and grazing beef cattle (Ritchie \& Roser, 2021). Fulfilling these pledges is only possible if the world reduces the number of animals farmed. With animal agriculture alone responsible for roughly one-fifth (Xu et al., 2021) of greenhouse gas emissions, meeting the $1.5^{\circ} \mathrm{C}$ target under the Paris Agreement will be impossible (Clark et al., 2020) without rapid and ambitious changes to global food systems. Crucially, this means changing how meat is made, through ground-breaking research and innovation. As scientists call for rapid changes to decarbonize the food system (Clark et al., 2020), new ways of making meat from plants and cultivating it from cells are starting to be recognised (The Good Food Institute \& Climate Advisers, 2021) as part of the solution. The Global Innovation Needs Assessment (ClimateWorks Foundation \& Foreign, Commonwealth and Development Office, UK government, 2021) study launched at the start of COP26 demonstrated the enormous potential of this approach. The report, funded by the UK Foreign, Commonwealth and Development Office and Climate Works Foundation, found that diversifying our protein supply to include plant-based and cultivated meat could be almost as beneficial as investing in solar power. As well as cutting

Seren Kell

serenk@gfi.org

1 Science and Technology Manager, The Good Food Institute Europe, Drève du Pressoir 38, 1190, Forest, Belgium 
global greenhouse gas emissions by $5 \mathrm{Gt}$ every year, the report found shifting towards sustainable proteins that could free up 640 million hectares of land-an area larger than the Amazon rainforest - for rewilding, carbon capture, or sustainable agriculture. And diversifying the protein supply could reduce average crop prices by $10 \%$-helping to tackle malnutrition. Renewable energy sources have undergone a revolution over the last decadewith researchers driving innovations that have helped cut the cost of solar photovoltaics by more than $85 \%$ between 2010 and 2020 . With global demand for meat set to increase by $73 \%$ by 2050 , we need scientists and engineers to transition their research focus towards advancing sustainable proteins if we're to stand a chance of meeting the Paris Agreement. To deliver a solar revolution for the meat industry, we'll need research to help sustainable protein options match animal products on taste, price, and scale. And funding is beginning to come through. The EU's Horizon Europe research funding programme calls for 2022 to have a strong theme of mitigating climate change and emphasising circularity across the bioeconomy, so there are clear opportunities for academics to submit proposals that advance plant-based and cultivated meat. For example, researchers could focus on identifying crops capable of withstanding climate change, as future potential ingredients for plant-based meat. Similarly, identifying novel ways to utilise waste feedstocks to produce protein through microbial fermentation holds great potential for sustainability. We need to build a robust ecosystem and leverage network effects to increase the hundreds of talented minds working on these solutions by 1000 -fold. By dedicating their talents to addressing key challenges-advancing innovations that improve taste and texture, bring prices down, and increase availability - researchers can make sustainable foods the default choice. The science is clear on this. As research from the University of Oxford found (Clark et al., 2020), it is impossible to achieve the aims of the Paris Agreement without a shift away from industrial animal agriculture. We have only just begun to scratch the surface, and there is a huge amount of research still needing to be done if we want to see plant-based and cultivated meat become an integral part of the global food supply. Through their work, researchers can address key industry questions and build the foundation of the global alternative protein field. Now is the time for other leading innovators to join us and transform the global food system. Publisher's Note: Springer Nature remains neutral with regard to jurisdictional claims in published maps and institutional affiliations.

\section{References}

Clark, M. A., Domingo, N. G. G., Colgan, K., Thakrar, S. K., Tilman, D., Lynch, J., Azevedo, I. L., \& Hill, J. D. (2020). Global food system emissions could preclude achieving the $1.5^{\circ}$ and $2{ }^{\circ} \mathrm{C}$ climate change targets. Science, 370(6517), 705-708. https://doi.org/10.1126/science.aba7357

ClimateWorks Foundation \& Foreign, Commonwealth and Development Office, UK government. (2021, November 1). Global Innovation Needs Assessments: Protein diversity. ClimateWorks Foundation. Retrieved January 6, 2022, from https://www.climateworks.org/wp-content/uploads/2021/11/GINAsProtein-Diversity.pdf

Glasgow Leaders' Declaration on Forests and Land Use - UN Climate Change Conference. (2021, November 2). COP26. Retrieved January 6, 2022, from https://ukcop26.org/glasgow-leaders-declaration-onforests-and-land-use/

The Good Food Institute \& Climate Advisers. (2021). Global Food System Transition is Necessary to Keep Warming Below $1.5^{\circ} \mathrm{C}$. The Good Food Institute. Retrieved January 6, 2022, from https://gfi.org/ 
wp-content/uploads/2021/04/FINAL_Climate-Advisers_Good-Food-Institute-Alternative-ProteinsReport.pdf

Joint US-EU Press Release on the Global Methane Pledge. (2021, September 18). The White House. Retrieved January 6, 2022, from https://www.whitehouse.gov/briefing-room/statements-releases/2021/ 09/18/joint-us-eu-press-release-on-the-global-methane-pledge/

Ritchie, H., \& Roser, M. (2021). Drivers of deforestation. Our World in Data. Retrieved January 6, 2022, from https://ourworldindata.org/drivers-of-deforestation

UN Environment Programme. (2021, May 6). Global Methane Assessment: Benefits and Costs of Mitigating Methane Emissions. UN Environment Programme. Retrieved January 6, 2022, from https://www.unep. org/resources/report/global-methane-assessment-benefits-and-costs-mitigating-methane-emissions

Xu, X., Sharma, P., \& Shu, S. (2021). Global greenhouse gas emissions from animal-based foods are twice those of plant-based foods. Nature Food. https://doi.org/10.1038/s43016-021-00358-x 